\title{
Missed Hoffa Fracture in Skeletally Immature Patient Complicated by Non-union Pseudoarthrosis: Case Report and Review of Literature
}

\author{
Ashraf Elazab $^{1 *}$, Ahmed Salama ${ }^{1}$ and Abdallah Alzahrani ${ }^{2}$ \\ ${ }^{1}$ Knee \& Shoulder and Sport Traumatology Clinic Dr. Ashraf Elazab Mansoura, Egypt
}

${ }^{2}$ Almana Hospital Dammam, KSA

Submission: November 11, 2019; Published: December 10, 2019

*Corresponding author: Ashraf Elazab, Knee \& shoulder and sport traumatology Clinic, Mansoura, Egypt

\section{Abstract}

Hoffa fractures are uncommon clinical entity typically seen in adults after high-energy trauma, and commonly missed. Moreover, it's extremely rare in children and young adolescents. According to our knowledge only 7 cases were reported in the literature with coronal fracture of the femoral condyle in children and young adolescents until the last search in 30 August 2019. Five of these seven cases discussed fresh fractures and other two cases discussed a missed Hoffa fractures complicated with non-union. In this study we present another case of missed coronal fracture of the lateral femoral condyle that subsequently went on to non-union and pseudoarthrosis in a 12 years old boy. The patient presented 4 months after motor vehicle accident with symptoms of right knee pain, snapping and instability. Radiological evaluation revealed a non-united lateral Hoffa fracture. The non-united fragment involved about two third of the lateral femoral condyle. operative intervention was our decision, diagnostic arthroscopy was done 1st then open arthrotomy using anterolateral approach for excision of pseudoarthrosis, open reduction and internal fixation of the fracture. Six months postoperative outcome was satisfactory, with full range of motion and return to sport. .

Keywords: Coronal fracture of the femoral condyle; Hoffa fracture; Pseudoarthrosis; Nonunion; Children and adolescents

Abbrevations: CT: Computed Tomography; MRI: Magnetic Resonance Imaging; ACL: Anterior Cruciate Ligament; ORIF: Open Reduction and Internal Fixation

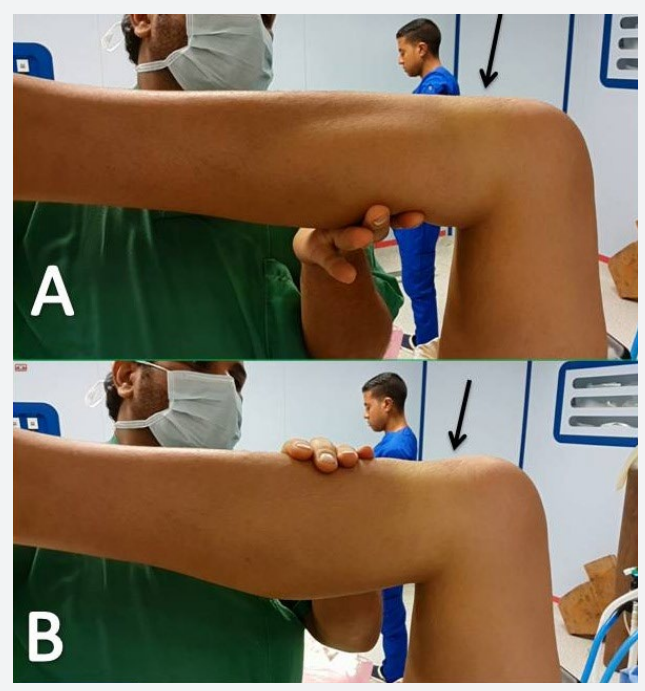

Figure 1: Clinical examination to the knee with neglected Hoffa fracture showing a positive posterior sag sign, the black arrow showed the normal position of the tibia in the upper(A) picture and the posterior sagging in the lower (B) picture. 


\section{Orthopedics and Rheumatology Open Access Journal (OROAJ)}

The purpose of this study was to present a rare case of missed coronal fracture of the lateral femoral condyle which is known as Hoffa fracture in a young adolescent complicated by pseudoarthrosis. In addition to review the literatures about previously reported non-union or pseudoarthrosis as a complication of this uncommon fracture in children and young adolescents. A 12-year-old patient presented to us 4 months after a motor vehicle accident with pain, swelling, and limping in his right knee. According to the patient family they went to a general hospital seeking for medical advice immediately after the trauma and $\mathrm{x}$ ray was done which have been evaluated by orthopaedic resident who decided for conservative management. Our Clinical examination revealed tender, swollen knee with antero-posterior instability which raise our suspicion for cruciate ligaments insufficiency (Figures $1 \& 2$ ). Radiological evaluation including standard $\mathrm{x}$ ray and CT scan showed isolated non-united Hoffa fracture of the lateral femoral condyle to the right knee (Figure 3). The fractured segment was about 2/3 of the lateral femoral condyle. MRI examination was done to evaluate cruciate ligaments and other intraarticular structures and showed no abnormalities except for the fracture. Therefore, we suggested that the antero-posterior instability that observed by clinical examination was due to instability at the fracture site of the lateral femoral condyle in which the femoral attachment of the ACL is present at the medial aspect of its postero-inferior portion. We decided for operative intervention without delay.

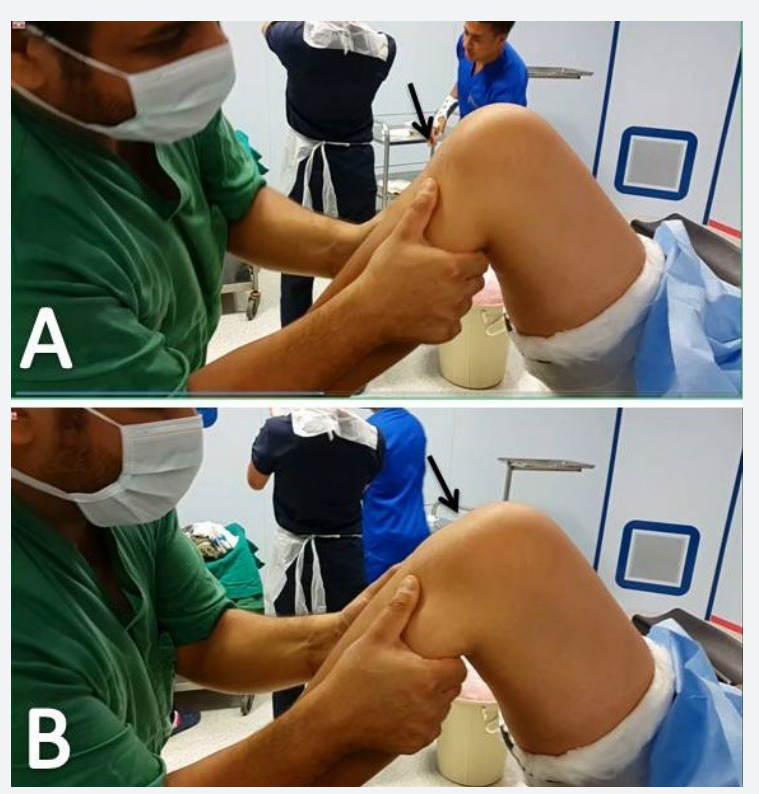

Figure 2: Clinical examination to the knee with neglected Hoffa fracture showing antero-posterior instability cleared by the black arrows in the upper $(A)$ and the lower(B) picture.

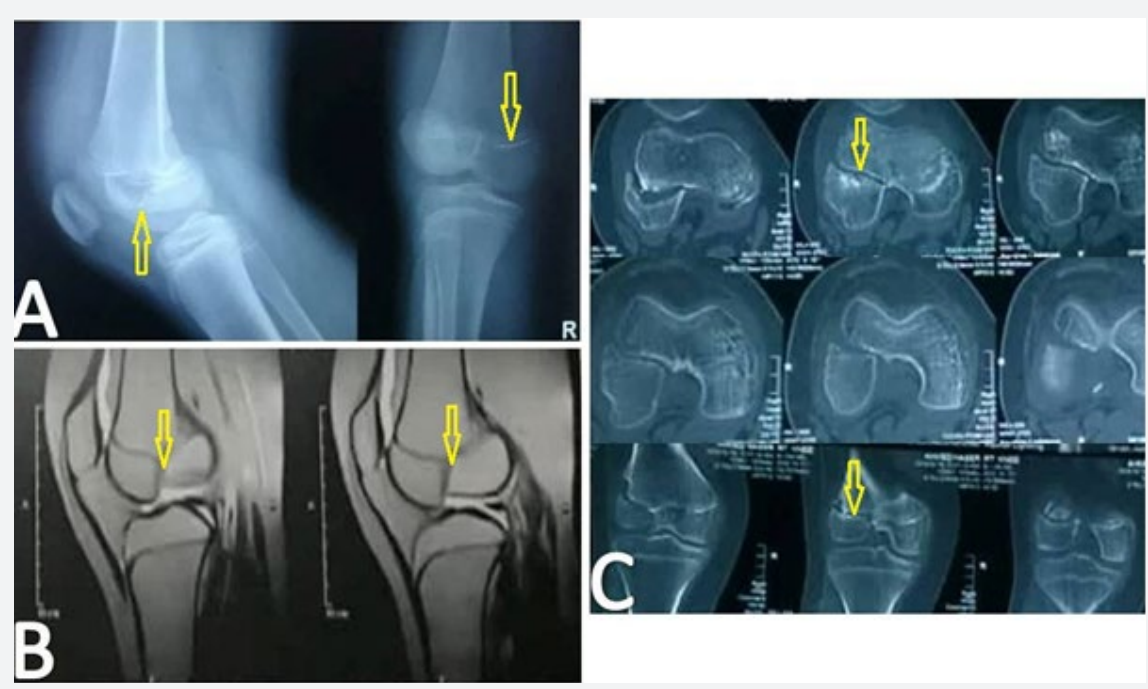

Figure 3: Standard $x$ ray $(A), M R I(B)$, and CT scan $(C)$ showing isolated non-united Hoffa fracture of the lateral femoral condyle to the right knee clarified by yellow arrows. 


\section{Orthopedics and Rheumatology Open Access Journal (OROAJ)}

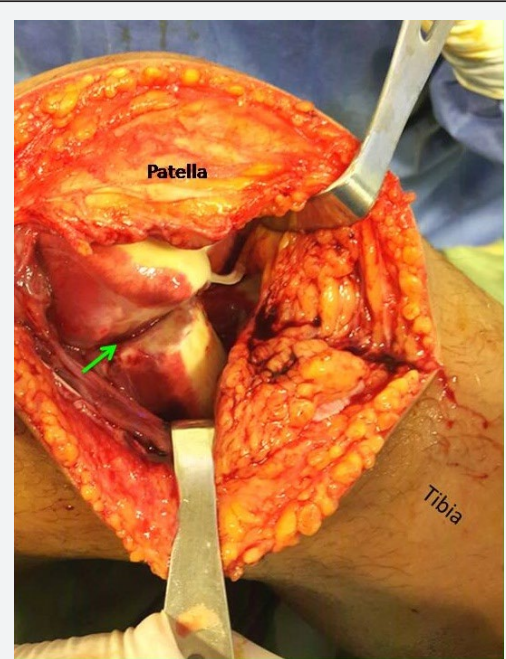

Figure 4: Lateral parapatellar approach showing the fracture site and the green arrow showed a clear picture of non-union and pseudoarhrosis.

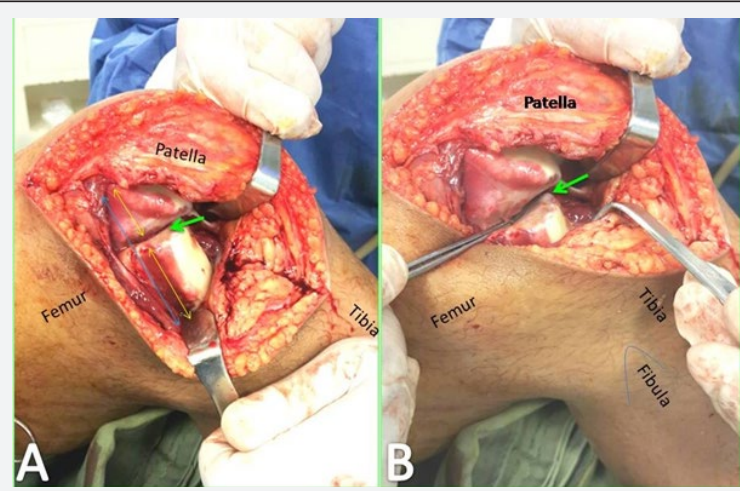

Figure 5: A. Lateral parapatellar approach showing the fracture site cleared by the green arrow and the non-united fragment involved about two third of the lateral femoral condyle

B. A clear picture of non-union pseudoarthrosis showed by the green arrow.

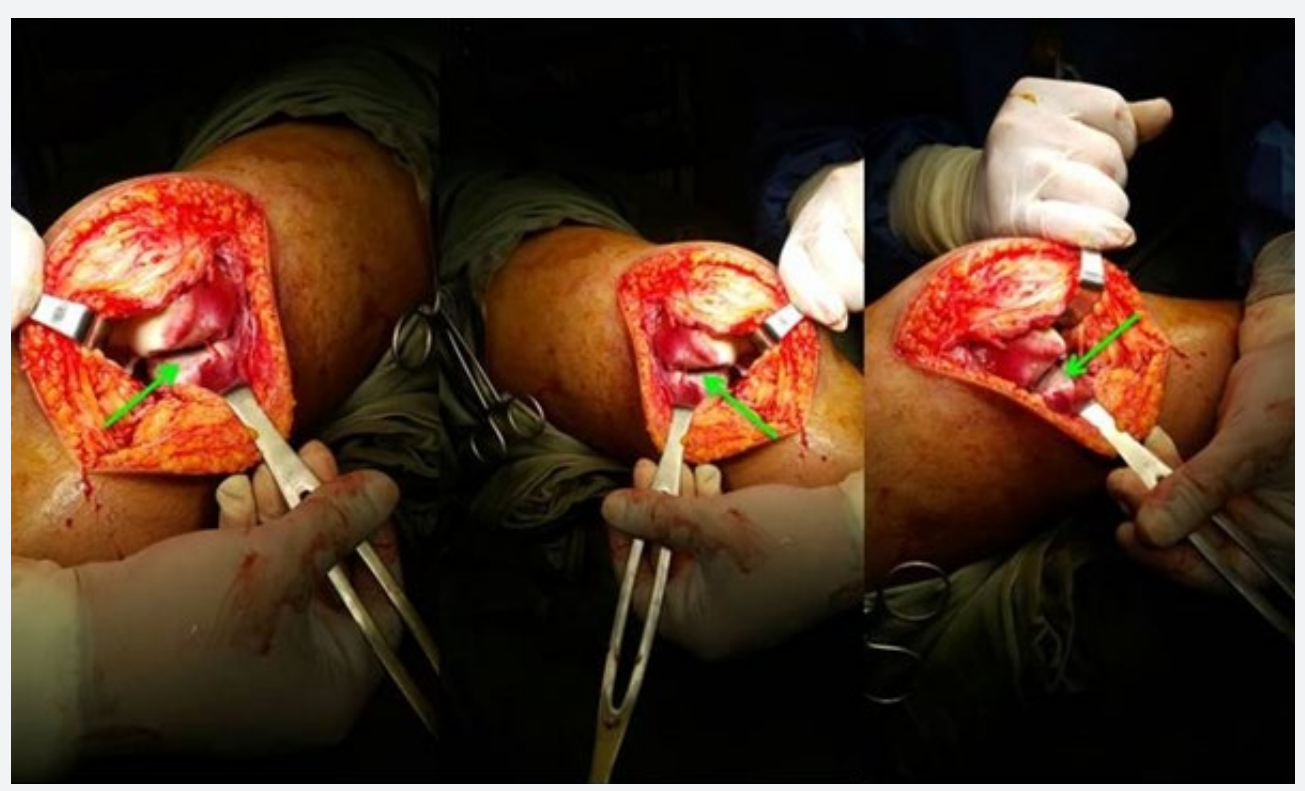

Figure 6: Different views showing the non-union pseudoarthrosis as a complication of neglected Hoffa fracture. 


\section{Orthopedics and Rheumatology Open Access Journal (OROAJ)}

Under spinal anaesthesia, the patient was positioned supine, tourniquet was elevated, and the usual draping was done. Before starting our definitive open reduction and internal fixation diagnostic arthroscopy was done to evaluate the cruciate ligaments, both menisci, and other intra-articular structures and we found no abnormalities except for the coronal fracture of the lateral femoral condyle. Moreover, antero-posterior stability was tested during arthroscopy and our suspicion about this issue was confirmed. Then, lateral parapatellar approach was used, delicate dissection was done until the fracture site was identified. The fractured segment was about $2 / 3$ of the lateral femoral condyle which was displaced posteriorly and laterally with marked posterolateral fibrous adhesions. Moreover, a clear picture of pseudoarthrosis was founded at the fracture site (Figures 4-6).
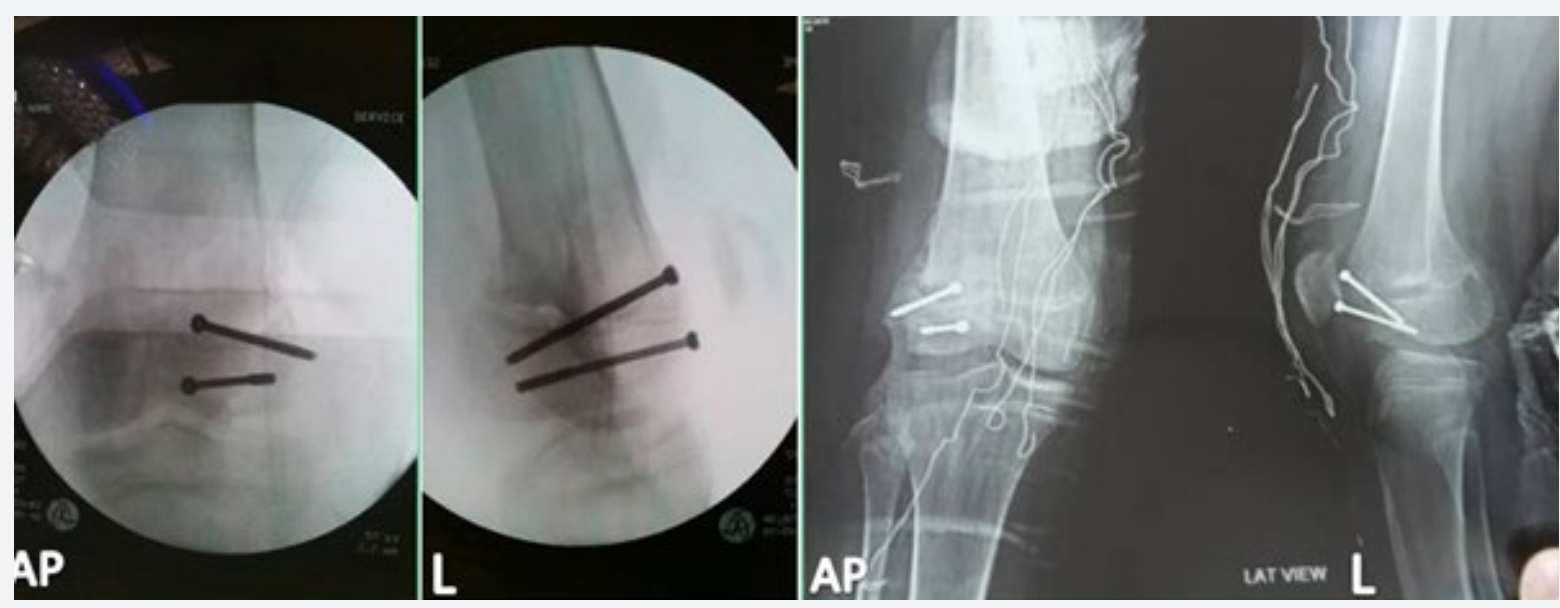

Figure 7: Postero-anterior and lateral $\mathrm{C}$ arm images and immediate postoperative postero-anterior and lateral $\mathrm{x}$ ray views showing the Hoffa fracture fixed with two cannulated screws.

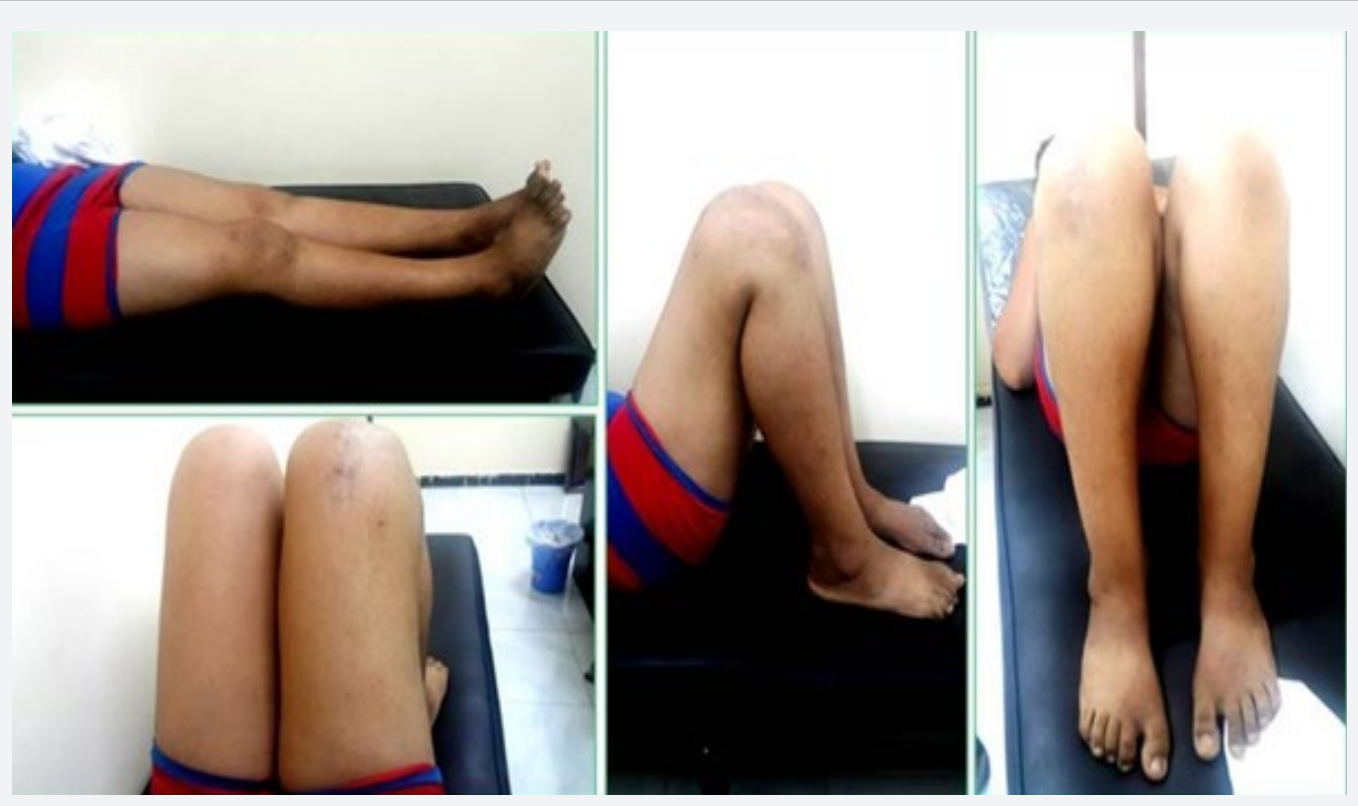

Figure 8: Six months post-operative follow up photographic pictures showing a complete range of motion.

After that, posterolateral adhesions were gently released and Pseudoarthrosis also excised until complete exposure of bone surfaces on both sides of the fracture site. A C-arm image intensifier was used to control reduction and screw placement. The reduction was obtained using a two-pointed reduction forceps one for coronal plane and the other for the sagittal plane reduction. After that, fixation was done using two cannulated screws (Figure 7). Postoperatively, The patient limb was splinted in above knee splint for 2 weeks. Followed by a physiotherapy program for range of motion restoration and muscle strengthening exercises. six months post-operative follow up showed a good fracture healing with complete range of motion and return to sport (Figures $8 \& 9$ ). 


\section{Orthopedics and Rheumatology Open Access Journal (OROAJ)}

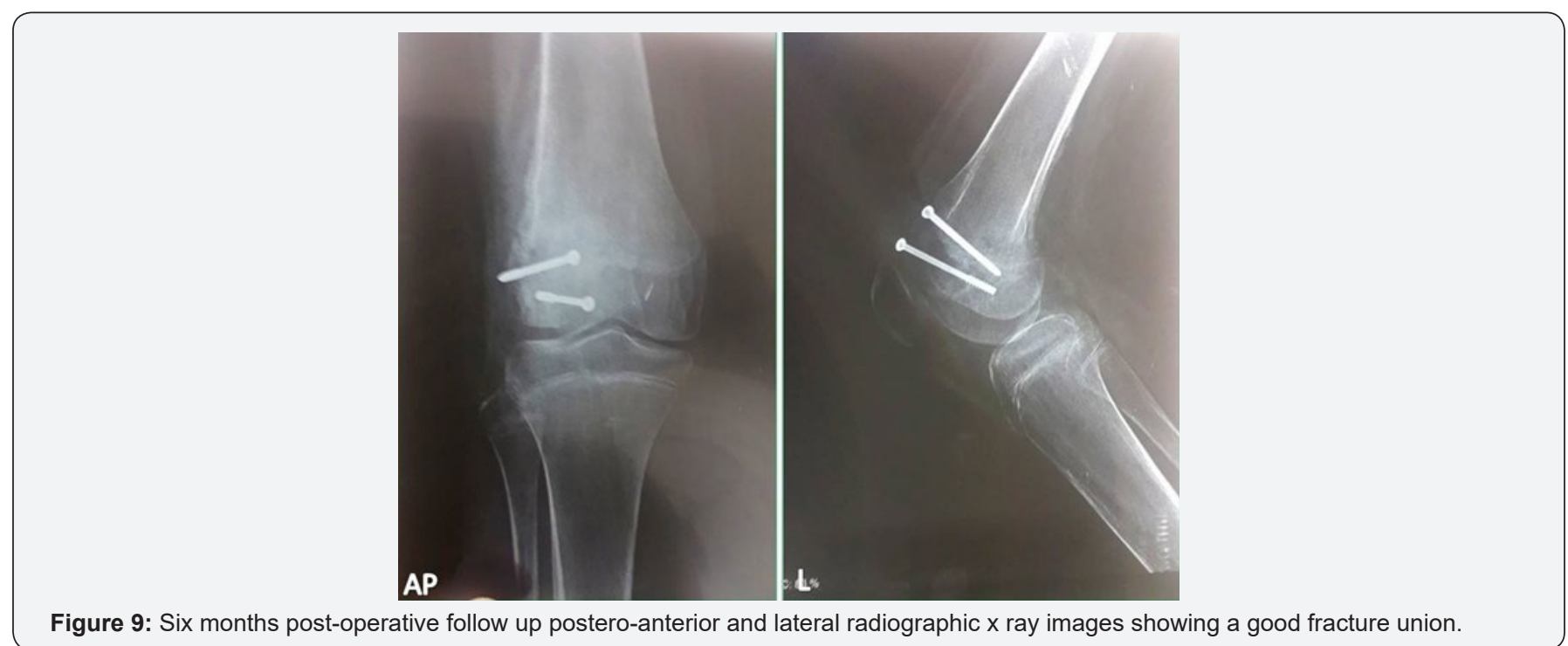

\section{Discussion}

Coronal fracture of the femoral condyle is an infrequent injury which was described for the first time by Hoffa in 1904 [1]. It is commonly emerges from the lateral femoral condyle in comparison to the medial condyle [2]. The usual cause of adult Hoffa's fracture is motor vehicle accidents [2,3]. While pediatric Hoffa's fracture can be due to motor vehicle accidents, sports injury, or even trivial injury [4]. In this case the injury was due to a motor vehicle accident. These types of fractures are rare in adult and its extremely rare in children. Moreover, it is easily missed Because the fracture is obscured in the anteroposterior projection by the intact anterior part of the condyle and the fracture can hardly be seen in the lateral view, if it is minimally displaced [3]. In our case the fracture was missed during examination in the emergency department by orthopedic resident despite obtaining a standard postero-anterior and lateral $\mathrm{x}$ ray immediately post injury. Therefore, advanced imaging utilities could be of a great value in diagnosis of these fractures especially when there is a suspicion of abnormality at standard x ray films.

Table 1: literatures previously reported Hoffa fractures in skeletally immature patients.

\begin{tabular}{|c|c|c|c|c|c|c|}
\hline Article & $\begin{array}{c}\text { Patient } \\
\text { age/gender }\end{array}$ & Surgery time & Approach & Fixation method & Fracture site & Outcome \\
\hline \multirow{3}{*}{$\begin{array}{l}\text { Flanagin BA et al. } \\
\qquad(2011)\end{array}$} & \multirow[b]{3}{*}{$14 / \mathrm{M}$} & \multirow[b]{3}{*}{ Immediate } & \multirow{3}{*}{$\begin{array}{l}\text { Diagnostic } \\
\text { arthroscopy \&arthrotomy } \\
\text { for ORIF }\end{array}$} & \multirow{3}{*}{$\begin{array}{l}\text { Four headless } \\
\text { compression } \\
\text { screws }\end{array}$} & \multirow{3}{*}{$\begin{array}{l}\text { Lateral femoral } \\
\text { condyle }\end{array}$} & 12 months post op \\
\hline & & & & & & $\begin{array}{l}1 \text { - Fracture } \\
\text { radiographically } \\
\text { healed }\end{array}$ \\
\hline & & & & & & $\begin{array}{l}\text { 2- Patient pain free } \\
\text { with restoration of } \\
\text { full knee motion and } \\
\text { return to sporting } \\
\text { activity. }\end{array}$ \\
\hline \multirow{3}{*}{$\begin{array}{l}\text { AlKhalife YI et al. } \\
\qquad(2018)\end{array}$} & \multirow{3}{*}{$12 / \mathrm{M}$} & \multirow{3}{*}{ Immediate } & \multirow{3}{*}{$\begin{array}{l}\text { Medial parapatellar } \\
\text { approach for ORIF }\end{array}$} & \multirow{3}{*}{$\begin{array}{c}\text { Two } 4.0 \mathrm{~mm} \\
\text { partially } \\
\text { threaded } \\
\text { cancellous screws }\end{array}$} & \multirow{3}{*}{$\begin{array}{l}\text { Medial femoral } \\
\text { condyle }\end{array}$} & 6 months post op \\
\hline & & & & & & $\begin{array}{l}\text { 1- Plain radiographs } \\
\text { and CT showed a well- } \\
\text { healed fracture }\end{array}$ \\
\hline & & & & & & $\begin{array}{l}\text { 2- walking without } \\
\text { support and without } \\
\text { pain and the knee } \\
\text { range of motion was } \\
15 \text { to } 130^{\circ}\end{array}$ \\
\hline \multirow{3}{*}{$\begin{array}{l}\text { Bali K et al. } \\
\text { (2011) }\end{array}$} & \multirow{3}{*}{$12 / \mathrm{M}$} & \multirow{3}{*}{ Immediate } & \multirow{3}{*}{ Subvastus approach } & \multirow{3}{*}{$\begin{array}{c}\text { Two large } \\
\text { fragment partially } \\
\text { threaded screws } \\
\text { placed from } \\
\text { anterior to } \\
\text { posterior in the } \\
\text { epiphysis }\end{array}$} & \multirow{3}{*}{$\begin{array}{l}\text { Medial femoral } \\
\text { condyle }\end{array}$} & 36-month post op \\
\hline & & & & & & $\begin{array}{l}\text { 1- he fractures was } \\
\text { united }\end{array}$ \\
\hline & & & & & & $\begin{array}{l}\text { 2- full extension and } \\
\text { approximately } 130^{\circ} \\
\text { flexion of knee }\end{array}$ \\
\hline
\end{tabular}




\section{Orthopedics and Rheumatology Open Access Journal (OROAJ)}

\begin{tabular}{|c|c|c|c|c|c|c|}
\hline \multirow{3}{*}{$\begin{array}{l}\text { Harna B et al. } \\
\qquad(2017)\end{array}$} & \multirow{3}{*}{$7 / \mathrm{M}$} & \multirow{3}{*}{ Immediate } & \multirow{3}{*}{ Swashbuckler approach } & \multirow{3}{*}{$\begin{array}{l}2.9 \mathrm{~mm} \text { Herbert } \\
\text { screws buried } \\
\text { under articular } \\
\text { cartilage }\end{array}$} & \multirow{3}{*}{$\begin{array}{l}\text { Bicondylar Hoffa's } \\
\text { fracture } r\end{array}$} & 6 months post op \\
\hline & & & & & & $\begin{array}{l}\text { 1- Fracture healing } \\
\text { achieved by } 10 \text { weeks }\end{array}$ \\
\hline & & & & & & $\begin{array}{l}2-0^{\circ}-130^{\circ} \text { painless } \\
\text { range of motion } \\
\text { achieved }\end{array}$ \\
\hline \multirow[b]{2}{*}{ Lal H et al. (2011) } & \multirow[b]{2}{*}{$9 / \mathrm{M}$} & \multirow[b]{2}{*}{ Immediate } & \multirow[b]{2}{*}{$\begin{array}{l}\text { Arthroscopically assisted } \\
\text { internal fixation }\end{array}$} & \multirow[b]{2}{*}{$\begin{array}{c}\text { Two } 4.5-\mathrm{mm} \\
\text { cannulated } \\
\text { cancellous screws }\end{array}$} & \multirow[b]{2}{*}{$\begin{array}{l}\text { Bicondylar Hoffa's } \\
\text { fracture } r\end{array}$} & $\begin{array}{c}\text { Radiographic union } \\
\text { was observed after } 8 \\
\text { weeks postoperative, }\end{array}$ \\
\hline & & & & & & $\begin{array}{c}\text { No signs of avascular } \\
\text { necrosis of femoral } \\
\text { condyle and no } \\
\text { radiological evidence } \\
\text { of osteoarthritis at } 3 \\
\text { years postoperative } \\
\text { follow up }\end{array}$ \\
\hline $\begin{array}{l}\text { McDonough, PW } \\
\text { et al. }(2000)\end{array}$ & 8/ M & $\begin{array}{l}\text { Five years } \\
\text { after a motor } \\
\text { vehicle } \\
\text { accident }\end{array}$ & ORIF & & $\begin{array}{l}\text { Lateral femoral } \\
\text { condyle }\end{array}$ & $\begin{array}{l}\text { Full range of motion } \\
\text { of the knee and no } \\
\text { evidence of growth } \\
\text { disturbance }\end{array}$ \\
\hline $\begin{array}{c}\text { Tripathy SK et al. } \\
\text { (2013) }\end{array}$ & $12 / \mathrm{M}$ & $\begin{array}{l}\text { 4-months } \\
\text { post injury }\end{array}$ & Posterolateral approach & $\begin{array}{c}\text { Two partially } \\
\text { threaded } \\
\text { cancellous screws }\end{array}$ & $\begin{array}{l}\text { Lateral femoral } \\
\text { condyle }\end{array}$ & $\begin{array}{c}\text { Radiographic union } \\
\text { was observed after } \\
3 \text {-month, Excellent } \\
\text { functional outcome } 2 \\
\text { years postoperative }\end{array}$ \\
\hline
\end{tabular}

According to our knowledge seven cases were reported in the literatures discussing Hoffa fractures in skeletally immature patients until last search at 30 august 2019 ( Table 1)[4-10] . Five of these seven cases were fresh fractures and early managed operatively with different approaches and different techniques and the result were satisfactory [4-8]. However, only two cases were described in the literatures as a missed Hoffa fracture in an eight year old girl and twelve year old boy went to a nonunion which managed operatively and fixed with cannulated screws and the result were satisfactory in the 1st case the child has virtually full range of motion of the knee and no evidence of growth disturbance, also in the second case radiographic union was observed after 3 months, and after 2 years of follow-up, the child had excellent functional outcome $[9,10]$. In this study we report another case of missed non-united lateral condyle Hoffa fracture in a twelve-year-old boy with a clear picture of pseudoarthrosis. Moreover, vigorous antero-posterior instability was observed during clinical examination, in spite of normal cruciate ligaments and other intraarticular structures in MRI examination.We referred this instability to the fracture geometry which is type I Hoffa fracture that extend from an extra-articular location at the junction of the posterior femoral shaft and the proximal aspect of the femoral condyle to the posterior aspect of the condylar articular surface. And the anterior cruciate ligament (ACL) insertion in addition to the popliteus tendon, and the lateral head of the gastrocnemius origin remain attached to the unstable non-united condylar fragment (figure 4).

Conservative management of these fractures supposed to be unsatisfactory as reduction of the fracture fragment is difficult to achieve and to maintain by closed means and it could leads to multiple complications like avascular necrosis, non-union and malunion $[2,3,8]$. Therefore, surgical stabilization is necessary to achieve satisfactory function [3]. Different approaches have been proposed according to the location of the fracture , including parapatellar approach as reported by Holmes et al.[3] in a case series of five Hoffa fractures and the results were satisfactory. Anterior midline approach was used by Patel et al. [11] in a series of seven adult patients with Hoffa fractures and the results were also good. lateral femoral epicondylar osteotomy was used by Juan M C et al. [12] in a case report of lateral Hoffa fracture and they supposed that this approach could allow to gain extensile exposure to the posterolateral articular structures of the knee, and makes easy the direct reduction and fixation of lateral coronal distal femoral fractures. In this case we did our open reduction, internal fixation with lag screws through a formal lateral parapatellar approach and the result was satisfactory. However, in our case due to fibrous union and the posterio-lateral adhesions, in addition to the obvious pseudoarthrosis, reduction was not so easy. Two reduction forceps were necessary to obtain reduction in both coronal and axial planes after complete excision of the fibrous tissue and pseudoarthrosis from the fracture site.

\section{Conclusion}

Hoffa fractures in children and young adolescents are extremely uncommon, easily missed fractures. Advanced imaging techniques including CT and MRI examination would complete the picture for accurate diagnosis of this kind of fractures. Early operative intervention could prevent unfavorable complications like pseudoarthrosis which could affect joint functions. 


\section{Conflict of Interest}

\section{Conflict of Interest}

The authors declare that they have no conflict of interest.

\section{Funding}

There is no funding source.

\section{Ethical approval}

This article does not contain any studies with human participants or animals performed by any of the authors.

\section{Consent for publication}

Written informed consent was obtained from the patient father for publication of this case report and any accompanying images.

\section{References}

1. Hoffa A (1904) Lehrbuch der Frakturen und Luxationen, Stuttgart: V erlag von Ferdinand Enke, 451.

2. Lewis SL, Pozo JL, Muirhead-Allwood WF. Coronal fractures of the lateral femoral condyle. J Bone Joint Surg Br 71(1): 118-120.

3. Holmes SM, Bomback D, Baumgaertner MR (2004) Coronal fractures of the femoral condyle: a brief report of five cases. J Orthop Trauma 18(5): 316-319.
4. Flanagin BA, Cruz AI, Medvecky MJ Medvecky (2011) Hoffa fracture in a 14-year-old. Orthopedics 34(2): 138.

5. AlKhalife YI, Alshammari AN, Abouelnaga MA (2018) Hoffa's fracture of the medial femoral condyle in a child treated with open reduction and internal fixation: A case report. Trauma Case Rep 14: 20-26.

6. Bali K, Mootha AK, Prabhakar S, Dhillon MS. Isolated Hoffa fracture of the medial femoral condyle in a skeletally immature patient. Bull NYU Hosp Jt Dis 69(4): 335-338.

7. Harna B, Goel A, Singh P, Sabat D (2017) Pediatric conjoint Hoffa's fracture: An uncommon injury and review of literature. J Clin Orthop Trauma 8(4): 353-354.

8. Lal H, Bansal P, Khare R, Mittal D (2011) Conjoint bicondylar Hoffa fracture in a child: a rare variant treated by minimally invasive approach. J Orthop Traumatol 12(2): 111-114.

9. McDonough PW, Bernstein RM (2000) Nonunion of a Hoffa fracture in a child. J Orthop Trauma 14(7): 519-521.

10. Tripathy SK, Aggarwal A, Patel S, Goyal T, Priya N (2013) Neglected Hoffa fracture in a child. J Pediatr Orthop B 22(4): 339-343.

11. Nimish B Patel, Nadeem A Lil, Neel M Bhavsar (2014) Coronal plane Hoffa fractures of the distal femoral condyle treated using an anterior approach. Gujarat Medical Journal 69(2): 99-102.

12. CJM (2018) Hoffa Fracture Treated using a Lateral Femoral Epicondylar Osteotomy: Case report. JOJ Case Stud 6(4).

\section{Your next submission with Juniper Publishers will reach you the below assets}

- Quality Editorial service

- Swift Peer Review

- Reprints availability

- E-prints Service

- Manuscript Podcast for convenient understanding

- Global attainment for your research

- Manuscript accessibility in different formats ( Pdf, E-pub, Full Text, Audio)

- Unceasing customer service

Track the below URL for one-step submission https://juniperpublishers.com/online-submission.php 